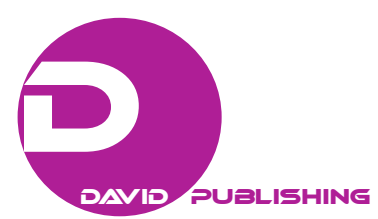

\title{
The Dimension of Entrepreneurial Characteristics in Young Entrepreneurs in the Creative Industry Field in Jakarta
}

\author{
Ati Cahayani, Aristo Surya Gunawan, Kurnianing Isololipu \\ Atma Jaya Catholic University of Indonesia, Jakarta, Indonesia
}

\begin{abstract}
To Indonesia, entrepreneurship still has to be enforced. By that reason, it requires comprehensive exploration about entrepreneurship and the related factors. Entrepreneurial characteristic is one of the most important factors when people discuss entrepreneurship because a new business could grow and sustain its life if only a strong entrepreneurial characteristic existed in the entrepreneur's inner-self. This research sought to know and explore the prominent entrepreneurial characteristics in young entrepreneurs in creative industry field in Jakarta as well as to know the entrepreneurial characteristics related to the success and continuity of the businesses carried on. Through this research, the mapping of entrepreneurial characteristics could be done, thus, the comprehension regarding the entrepreneurial characteristics in young entrepreneurs could be achieved. This research uses quantitative and qualitative methodology. Respondents for quantitative data were chosen by purposive techniques. Total respondents for quantitative data are 150 young entrepreneurs who run their businesses in the creative industry field located in five regions in Jakarta. The respondents are the owners of one creative industry. Out of those 150 respondents, 15 people were interviewed to obtain qualitative data that need more in-depth data. The technique to determine the informants was also done through purposive technique. Those 15 informants are business owners in the creative industry field in five regions of capital city who have bachelor's degree and are not older than 35 years old. One of the results of this research is that from the 15 tested characteristics, three entrepreneurial characteristics that have the highest points from the young entrepreneurs in the creative industry field in Jakarta region are responsibility, perseverance, and optimism.
\end{abstract}

Keywords: entrepreneurial characteristic, young entrepreneurs, creative industry

\section{Introduction}

Entrepreneurship is the driving force of nation's economy, because entrepreneurship can create new industrial sectors, new businesses, and most importantly, new job fields. According to economist Didik J. Rachbini, as quoted by Iwantono (2002), one of the indicators says that a nation is economically forward when the existence of entrepreneurs is more than $2.5 \%$ from its total number of citizens. Ciputra (2009) said, the

Ati Cahayani, doctor of education management, Department of Business Administration, Faculty of Business Administration and Communication Sciences, Atma Jaya Catholic University of Indonesia, Jakarta, Indonesia.

Aristo Surya Gunawan, master of management (major in finance), Department of Business Administration, Faculty of Business Administration and Communication Sciences, Atma Jaya Catholic University of Indonesia, Jakarta, Indonesia.

Kurnianing Isololipu, doctor of business administration, Department of Business Administration, Faculty of Business Administration and Communication Sciences, Atma Jaya Catholic University of Indonesia, Jakarta, Indonesia.

Correspondence concerning this article should be addressed to Ati Cahayani, Jl. Jenderal Sudirman Kav 51, Jakarta Selatan, Jakarta, 12930, Indonesia. 
amount of entrepreneurial activities in Indonesia is still very few, because approximately, only $0.18 \%$, or around 400,000 entrepreneurs. That amount is still considered as very few. It requires $2 \%$ of entrepreneurs in a country to promote the economic growth in that country, as said by Agus Muharam, Secretary of State Ministry for Cooperatives and Small Medium Entreprises (Akbar, 2015). The lack of entrepreneurs demands government or general society to keep providing maximum efforts to create new entrepreneurs.

As referred above, entrepreneurship can generate new job fields. That factor can make entrepreneurship as one of the solutions to reduce unemployment rate. For that, to those who have established the businesses, no matter if it is small, medium, or large, it is hoped that they can expand and sustain the development and sustainability of their businesses, so that it can contribute to Indonesia's economic growth. As to be confirmed by the Indonesian Minister of Manpower and Transmigration, Muhaimin Iskandar, "Entrepreneur can be one of the strong pillars of national economy to face global economic crisis and as solution to reduce poverty as well as to absorb unemployment” (Nur Maftuhah, 2012). Entrepreneurs' function was shown when Indonesia faced the 1997 monetary crisis. After the monetary crisis in 1997, the entrepreneurial activities showed a drastic improvement, from only 7,000 small businesses in 1980 to 40 million in 2001 (Margiman, 2008).

It can be said that, more and more businesses are developing, starting from micro, small, and medium businesses to businesses with large capital. The small businesses are dominated by the agriculture, forestry, farming, and fishery sectors (53.5\%); and large businesses in the processing sector (35.4\%) (Margiman, 2008). Indeed, the sectors mentioned have been existed for a long time in the Indonesia's business environment. But, with the development of knowledge, technology, and managerial skills, new industries start to emerge in the business field. One of the newest and rapidly growing businesses is creative industry.

Creative industry is defined as industry that comes from creativity, skills, and individual talent to create welfare and job fields by producing and exploiting individual creation resource and production resource (Indonesian Ministry of Trade, 2008). In this industry, the creativity that comes from human resource holds important role because it is originated from people's thinking that is supported by the existed facilities. The scope of creative industry is quite wide; it covers 14 sub sectors, which are:

(1) Architecture

(2) Design

(3) Fashion

(4) Film, video, and photography

(5) Crafting

(6) Computer and software service

(7) Music

(8) Performance art

(9) Publishing and printing

(10) Advertisement

(11) Interactive games

(12) Research and development

(13) Art show

(14) Television and radio

Many of the creative industries are run by young entrepreneurs. As delivered by the Minister of Tourism and Creative Economy, Mari Elka Pengestu, "Young people are the important actors of creativity economy 
because they have passion and creativity, and it is hoped to maintain the discernment and local traditions" (Sundari, 2012). Such thing is possible because young people in the present time are aware that through skills and hobbies that they have, they can create businesses and even provide job fields.

Creative industry is closely related to the creative economy because the creative industry in a country can contribute to that country's creative economy progression. This thing as quoted by Anugrah and Cahayani (2012) from Howkin's opinion, “creative industry is the core of creative economy”. Besides, John Howkins, as quoted by Anugrah and Cahayani (2012), said that creative economy is a part of economic activity that makes creativity, culture, and cultural heritage as well as environment, as the pedestals for the future.

But, even though it is seen that most of the businesses that entrepreneurs run are small and medium scaled sizes, it does not mean that entrepreneurship is an easy job. Entrepreneurial activities cannot be seen as easy. To start a business, to develop it from a small scale to a larger scale, and to maintain its sustainability, require yearly-long process. Not to mention, the occurrence of problems in the business is due to external (monetary crisis, increase in prices, and others) or internal factors (human resource, management, and others). To face such conditions, it is obvious that strong entrepreneurial characters are needed.

An entrepreneur also must possess certain characteristics to achieve success and the continuity of the business. In order to do development and sustainability, strong entrepreneurial character is one of the prerequisites. As said by Margiman (2008), by looking at the entrepreneurship profiles in Indonesia, thus the most crucial thing to do is the development of the spirit and the character of true entrepreneurs. Entrepreneurship is not done due to force and only making it as a temporary state.

Earlier researches about entrepreneurial characteristics were done on different research subjects. The research regarding the entrepreneurial spirit in women member of cooperative in Bojonegoro by Iedarwati, Isololipu, and Cahayani (2010) obtained data that personality characteristic is more prominent if compared to other two characteristics, which are managerial and agent of change. The other research of the same topic was done on young entrepreneurs who are Business Administration Department alumni by Cahayani, Gunawan, Iedarwati, and Isololipu (2011) shows that the characteristics of agent of change are stronger than the other two characteristics.

This research continues the two previous researches on the dimension of entrepreneurial characteristics to clarify and emphasize that the characteristics of entrepreneurship are required to develop and sustain a business. By focusing on the entrepreneurial dimension as the subject of the research, this time, thus it is hoped to provide understanding about entrepreneurial characteristics in various groups. This mapping will provide a more comprehensive knowledge source regarding certain groups related to their entrepreneurial characteristics.

Based on the explained background, these are the purposes that are intended to be achieved:

(1) To know the strengths of entrepreneurial characters in young entrepreneurs in the creative industry field in Jakarta.

(2) To know the entrepreneurial dimension in young entrepreneurs in the creative industry field in Jakarta.

(3) To explore the prominent entrepreneurial characters in young entrepreneurs in the creative industry field in Jakarta.

(4) To identify the entrepreneurial characters those support the success and the continuity of the business.

This article contains five sections: 1) Introduction; 2) Literature Review; 3) Research Method; 4) Research Result and Discussion; and 5) Conclusions and Recommendations. 


\section{Literature Review}

Entrepreneurship is the central theme that will be explored and developed in this research so that main idea among this research and the previous two researches can be obtained to enrich the comprehension about both theoretically and practically good entrepreneurship.

There are many definitions about entrepreneurship. One definition delivered by Accenture (2001) is "The creation of value by people and organisations working together to implement an idea through the application of creativity, drive, and a willingness to take what might commonly be seen as risks". The other definition is from Hisrich, Peters, and Sheperd (2013). Hisrich et al. (2013) said that entrepreneurship is a "process of creating something new and assuming the risks and the rewards". From those two definitions, it could be concluded that entrepreneurship is related with creativity and risk taking. So, it can be said that entrepreneur is a person who has creative and risk taking characteristic. Creativity and risk taking are two of some entrepreneurial characteristics that are important for an entrepreneur to achieve success and the continuity of the business.

There are some views from some academicians about what are the characteristics that are needed by people to be a successful entrepreneur. These are the characteristics of a successful entrepreneur according to Sutanto (2002):

(1) Creative and innovative

(2) Highly ambitious

(3) Energetic

(4) Confidence

(5) Smart and love to socialize

(6) Hardworking

(7) Risk taker

(8) Initiative and responsible

(9) Independent

(10) Optimism to achieve success

(11) Positive thinking

(12) Diligent

(13) And others

Longenecker, Moore, and Petty (2001) said that a successful entrepreneur has four main characteristics, which are: the need to achieve success, the need to take risks, confidence, and strong motivation. Soesarsono (2002) said that entrepreneur covers several important elements and those are: cognitive element, psychomotor element, affective element, and intuition element. Meredith (2002) said that out of many characteristics of entrepreneur mentioned by many experts, there are several intrinsic characteristics that must be possessed by entrepreneurs, which are:

(1) Self confidence

(2) Task oriented

(3) Risk taking

(4) Leadership

(5) Creative and innovative

(6) Visionary 
To be a successful entrepreneur, the main requirement is to have entrepreneurial spirit. Entrepreneurial spirit is determined by knowledge and business experience. So, an entrepreneur is someone who has the spirit and ability to create something new and different or also called as creative and innovative ability. This ability is reflected in the ability as well as the will to start a business, seek opportunities, and dare to bear the risks taken.

Even, Hornaday in Kuratko and Hodgetts (2007) explained clearly the 42 characteristics that are often shown inside of an entrepreneur. With those characteristics, it is possible if everyone wants to be an entrepreneur. The thing that differentiates a successful and reliable entrepreneur with the other ones is the way they process the imagination and creative thinking with the systematic and logical processing ability (Kuratko \& Hodgetts, 2007).

Wickham (2004) explained that an entrepreneur can be considered as a manager, agent of change, and individual who has psychological condition, personality, and certain characteristics. Those three are run by an entrepreneur with their own functions.

\section{Research Method}

The technique to determine the respondents is done through the purposive technique. The researchers chose 150 young entrepreneurs as the respondents who run their businesses in the creative industry field located in five regions in Jakarta. The respondents are the owners of one creative industry out of 14 creative industries set by Indonesian Ministry of Tourism and Creative Economy.

Out of those 150 respondents, 15 people were interviewed. The researchers collected qualitative data through interviews to obtain more in-depth data. The technique to determine the informants was also done through purposive technique, these informants are business owners in the creative industry field in five regions of capital city who have bachelor's degree and are not older than 35 years old.

\section{Variables Operationalization}

In this research, three entrepreneurial roles will be examined according to Wickham (2004), those are managerial, agent of change, and personality with different characteristics, as expressed by Hornaday (Kuratko \& Hodgetts, 2007), Meredith (2002), and Longenecker et al. (2001).

The research's variable is the entrepreneurial dimension that covers three characteristics which are as follow:

(1) Personality characteristic

The examined personality characteristics were confidence, perseverance, independence, responsibility, and pleasant personality.

(2) Managerial characteristic

The examined managerial characteristics were the ability to take decisions quickly, ability to take calculated risks, optimism, orientation to clear goals, and profit orientation.

(3) Agent of change chracteristic

The agent of change characteristics that are examined in this research are initiative, aggressiveness, creativity, efficacy, and positive response to challenge.

\section{Data Collection and Analysis}

The questionnaire in this research used Likert scale, that is a scale that demands respondents to respond to each question in five levels of agreement which are: Very Agree (5 points), Agree (4 points), Quite Agree (3 points), Less Agree (2 points), and Not Agree (1 point) 
The next step was to tabulate the data. From each tested variable, the answers from the respondents (Very Agree, Agree, Quite Agree, Less Agree, and Not Agree) were counted. After the data tabulation was done, thus the next step was to count the average or mean value of each tested sub variable. The average values were found by using the mean score formula. After the mean score of each sub variable was counted, thus overall mean score of each variable could be counted.

Qualitative research was also done through the interview's data. The qualitative data analysis used was content analysis. In the content analysis, the researchers tried to analyze deeper qualitative answers obtained from the interview.

\section{Research Results and Discussion}

\section{Respondent's Profile}

Seen from the recorded respondents' profiles, the majority of the respondents in this research have descriptions as below:

- Gender: female (64\%)

- Last formal education: less than or equal to high school (63\%)

- Age: less than or equal to 35 years old (61\%)

- Married and have family (71\%)

- Never change the business (63\%)

- The age of the business: more than or equal to five years (67\%)

- The business' turnover: less than or equal to IDR 100 million monthly (51\%)

- Business fields: fashion (51\%), handicraft (15\%), and computer’s hardware and software business (9\%)

\section{Quantitative Analysis}

In the first part, the researchers tested the entrepreneurial characteristics, regarding the importance of each characteristic variable that he/she needs to have to run his/her business. The entrepreneurial characteristics dimension covers three characteristics which are the personality characteristics, managerial characteristics, and agent of change characteristics. Below, in Table 1, there will be explanations regarding the average value for each personality characteristic, managerial characteristic, and agent of change characteristic. The greater is the score, the stronger is the entrepreneurial character in the respondents.

Table 1

Entrepreneurial Characteristics Mean Score

\begin{tabular}{|c|c|c|c|c|c|c|}
\hline \multirow[b]{2}{*}{ No. } & \multicolumn{6}{|c|}{ Entrepreneurial characteristics } \\
\hline & $\begin{array}{l}\text { Personality } \\
\text { characteristics }\end{array}$ & Mean score & $\begin{array}{l}\text { Managerial } \\
\text { characteristics }\end{array}$ & Mean score & $\begin{array}{l}\text { Agent of change } \\
\text { characteristics }\end{array}$ & Mean score \\
\hline 1 & Responsibility & 3.90 & Optimism & 3.74 & Aggressiveness & 3.53 \\
\hline 2 & Perseverance & 3.86 & $\begin{array}{l}\text { Orientation to clear } \\
\text { goals }\end{array}$ & 3.56 & Efficacy & 3.47 \\
\hline 3 & Confidence & 3.72 & Profit orientation & 3.37 & $\begin{array}{l}\text { Positive response } \\
\text { to challenges }\end{array}$ & 3.38 \\
\hline 4 & Independence & 3.69 & $\begin{array}{l}\text { Ability to take } \\
\text { calculated risk }\end{array}$ & 3.29 & Initiative & 3.38 \\
\hline 5 & $\begin{array}{l}\text { Pleasant } \\
\text { personality }\end{array}$ & 3.42 & $\begin{array}{l}\text { Ability to make } \\
\text { decision quickly }\end{array}$ & 3.23 & Creativity & 3.37 \\
\hline & Overall mean score & 3.72 & Overall mean score & 3.44 & Overall mean score & 3.43 \\
\hline
\end{tabular}


From all 15 tested entrepreneurial characteristics variables, they are three character variables that have the highest mean score values in each entrepreneurial characteristic dimension. This research also generates top 10 characteristics that are the most prominent as listed in Table 2. While if those 15 tested entrepreneurial characteristic variables are arranged from the highest mean score value without grouping it into three characteristic dimensions, that will produce 10 prominent characteristic variables, as listed in Table 3 below.

Table 2

Top 10 Prominent Entrepreneurial Characteristics Based on Top Three Entrepreneurial Characteristics in Each Dimension

\begin{tabular}{llll}
\hline No. & Entrepreneurial characteristics & Characteristics dimension & Mean score \\
\hline 1 & Responsibility & Personality & 3.90 \\
2 & Perseverance & Personality & 3.86 \\
3 & Optimism & Managerial & 3.74 \\
4 & Confidence & Personality & 3.72 \\
5 & Orientation to clear goals & Managerial & 3.56 \\
6 & Efficacy & Agent of change & 3.53 \\
7 & Aggressiveness & Agent of change & 3.47 \\
8 & Positive response to challenges & Agent of change & 3.38 \\
9 & Initiative & Agent of change & 3.38 \\
10 & Profit orientation & Managerial & 3.37 \\
\hline
\end{tabular}

Table 3

\section{Fifteen Entrepreneurial Characteristics Arrangement}

\begin{tabular}{llll}
\hline No. & Entrepreneurial characteristics & Characteristics dimension & Mean score \\
\hline 1 & Responsibility & Personality & 3.90 \\
2 & Perseverance & Personality & 3.86 \\
3 & Optimism & Managerial & 3.74 \\
4 & Confidence & Personality & 3.72 \\
5 & Independence & Personality & 3.69 \\
6 & Orientation to clear goals & Managerial & 3.56 \\
7 & Efficacy & Agent of change & 3.53 \\
8 & Aggressiveness & Agent of change & 3.47 \\
9 & Pleasant personality & Personality & 3.42 \\
10 & Positive response to challenges & Agent of change & 3.38 \\
\hline
\end{tabular}

From Table 3, it is shown that the personality characteristics' dimension is dominated by having five tested personality characteristics in the top 10 list. Besides, there are three agents of change characteristics and two managerial characteristics that complete the list. The personality characteristics' domination can also be seen by looking at the four personality characteristics' dimensions in the top live list. The comparison of the characteristics dimensions can be seen in Table 1, it shows that the overall mean score value of personality characteristics' dimension is higher than the managerial characteristics' dimension and agent of change's dimension.

It is seen that the personality characteristics dimension as the prominent dimension. This is strengthened by the fact that four out of five variables of personality characteristic are in the upper five ranks of the most prominent entrepreneurial characteristics in the examined respondents, who are the young entrepreneurs working in the creative industry field in Jakarta. The prominent entrepreneurial characteristics are responsibility, perseverance, optimism, confidence, and independence. 
Furthermore, researchers questioned five important characterial factors that an entrepreneur must have. Researchers questioned those five factors by using priority scale, from the first until the fifth. The result of the top three characterial factors concluded from the respondents' answers are shown in Table 4 . While Table 5 will explain the five factors considered as the most important ones to the respondents by neglecting the first priority scale to the last one. From Table 4, it can be seen that the personality characteristic variables are dominating; even the upper three ranks of the first priority scale to the third scale are all personality characteristics variables. None of the managerial characteristics variable or the agent of change is in the top three of the first to the third priority scales. In the fourth and fifth scales, the three mentioned answers are dominated by the managerial characteristics variable and the agent of change variable. From Table 5, the domination from the personality characteristic variable can also be seen, where four out of five characters are considered as the most important ones to be owned by an entrepreneur, which are the variables of: "perseverance”, "responsibility”, “confidence”, and “independence”. The managerial characteristic, "optimism” completes the top five characteristics.

Table 4

The Five Characters Considered Being the Most Important Ones to an Entrepreneur (Based on the Order of the First Answer to the Fifth Answer)

\begin{tabular}{lll}
\hline The order of priority & Entrepreneurial characteristics & \% to total answers in order of priority \\
\hline \multirow{3}{*}{1} & Confidence & $39.33 \%$ \\
& Perseverance & $32.67 \%$ \\
& Responsibility & $11.33 \%$ \\
\hline \multirow{2}{*}{2} & Perseverance & $28.67 \%$ \\
& Responsibility & $23.33 \%$ \\
3 & Independence & $16.00 \%$ \\
\hline \multirow{3}{*}{4} & Independence & $22.67 \%$ \\
& Responsibility & $20.00 \%$ \\
& Perseverance & $14.67 \%$ \\
\hline \multirow{2}{*}{5} & Responsibility & $22.67 \%$ \\
& Optimism & $13.33 \%$ \\
& Creativity & $8.00 \%$ \\
\hline
\end{tabular}

Table 5

The Five Characters Considered to be the Most Important Ones to an Entrepreneur (by Ignoring the Order of Priority)

\begin{tabular}{lll}
\hline Priority & Entrepreneurial characteristics & \% to total answers \\
\hline 1 & Perseverance & $16.93 \%$ \\
2 & Responsibility & $16.67 \%$ \\
3 & Confidence & $14.00 \%$ \\
4 & Independence & $11.20 \%$ \\
5 & Optimism & $8.53 \%$ \\
\hline
\end{tabular}

This confirms the results of this research in the first section above, that the ones that are considered as the most important factors to determine success are entrepreneurship and personality characteristics. A person may 
only have strength in managerial skill or the spirit of agent of change, but if he/she does not possess the entrepreneurial characteristics, then surely his business will not run properly.

\section{Qualitative Analysis}

From the 15 informants, there were eight informants who are engaged in the creative industries of fashion and the two engaged in the fashion that is related to that of screen printing and sequin mounting. This is consistent with the data from the Indonesian Ministry of Trade that stated that fashion tops of the creative industries, as many as $43.71 \%$. Here is the qualitative analysis for each dimension of entrepreneurial characteristics.

\section{(1) Personality characteristics}

Those 15 informants claimed that independence and confidence are needed in order to become entrepreneurs, albeit with a different explanation. This is slightly different from the quantitative data, where confidence and independence ranked the third and fourth in the personality aspect. One informant who is in the interactive gaming business claimed that "We must be confident because confidence is the same as optimism when running a business, we should be optimistic, but if we are not optimistic then it is better to not run a business". In essence, they said, it is impossible for a business to succeed if the business owners do not have confident attitude, which will be reflected in their everyday behavior. Entrepreneurs who are not confident will not be able to convince other parties of their businesses, regarding their products and services. And, in the end, it will lead to the death of their businesses. Regarding independency, an informant said, "Independence: if you can do it by yourself, why should rely on others. That is a genuine entrepreneur”. Apparently, entrepreneurship has been synonymous with independence, because one of the goals of entrepreneurship is to create new jobs, which means independency, not depending on others, and not relying on others to earn a living.

(2) Managerial characteristics

Regarding managerial aspect, the informants said that a decision could be a good decision if it taken with good consideration, sufficient data, and good timing. This is in line with the quantitative data, where the claim about how a decision should be taken quickly and does not occur in the first position. While, regarding optimism to achieve success, their answers about how they need confidence, are related to the managerial aspect regarding optimism to achieve success. Thus, it can be said that the 15 informants have optimism, which is in line with the quantitative data, where optimism sits in the highest position.

(3) Agent of change characteristics

The 15 informants agree that nothing is certain in this life, thus as entrepreneurs, they are required to take risks and have confidence so they can face the future. An informant mentioned something interesting about change: "To say uncertainty is scary or not, it will depend on the person. All these things are uncertain. Our mindset/paradigm has to change. We must try to find info on how to face the challenges in the future”. And an informant said "If you are afraid of the risk, do not do it". Their various answers have the same point, that is, business must be full of uncertainties, and they have no more fear to face uncertainties in the business world that they pursue.

\section{Conclusions and Recommendations}

From the elaborated results of the research above, several things can be concluded as follow:

(1) From the 15 tested characteristics, three entrepreneurial characteristics that have the highest points 
from the young entrepreneurs in the creative industry field in Jakarta region are: responsibility, perseverance, and optimism. The next characteristics are confidence and independence, as these two characteristics fulfill the top five list from the 15 tested characteristics.

(2) The personality characteristic dimension is the strongest entrepreneurial characteristic that is the strongest and most prominent one in the young entrepreneurs in the creative industry field in Jakarta region.

(3) The most prominent entrepreneurial characteristics in the young entrepreneurs in the creative industry field in DKI Jakarta who were the samples in the deeper interview are: independence and confidence from personality characteristic, then optimism from managerial characteristic, and efficacy from agent of change characteristic.

(4) There are five entrepreneurial characteristics that are considered as the most important ones to maintain success and the continuity of the business, which are perseverance, confidence, independence, optimism, and aggressiveness.

As the complementary from the conclusions made the writers express these recommendations as follow.

\section{Scientific Recommendations}

This research concludes a different conclusion with the other researches conducted by Cahayani et al. (2011). This shows that the research regarding entrepreneurial characteristics is an interesting research and this needs to be expanded to enrich the source of knowledge regarding the entrepreneurial characteristics from the young entrepreneurs.

Researchers suggest that the next research should focus on more specific respondents and focus on only one creative industry, for example, the young entrepreneurs who are involved in the fashion industry. By focusing on one creative industry field, it is hoped to explore deeper entrepreneurial characteristic dimension that is relevant to the industry field he/she is involved in.

\section{Practical Recommendations}

The result of this research is to clarify that the most important factor in entrepreneurship is related to the personality of the entrepreneur. This might be different from the perception of university students or young people in general, who think that the investment of the capital is the most important factor in entrepreneurship.

It is undeniable that entrepreneurship requires capital, but the most important thing is not to start business with money, but how to manage the money. If people want to create a business, thus, the more important thing is to thrive the growth of the business and to sustain it. In order for the business to develop and be sustained, the entrepreneur has to possess strong character.

Thus due to that, it is important for tertiary education institutions to introduce entrepreneurship to their students. The entrepreneurship topic is not only about how to start a business, but further, to shape the tough entrepreneurial character in their students. Through the appropriate character formation process, it will form strong and tough personalities to the young entrepreneurs who are able to not just starting businesses but able to grow and sustain their businesses.

\section{References}

Accenture. (2001). Liberating entrepreneurial spirit. Retrieved from http://www.accenture.com

Akbar, C. (2015). Jumlah wirausaha Indonesia baru 0,18 Persen. Retrieved from http://www.hidayatullah.com/berita/nasional/read/2015/11/11/83135/jumlah-wirausaha-indonesia-baru-018-persen.html 
Anugrah, C., \& Cahayani, A. (2012). Sosialisasi ekonomi kreatif terhadap generasi muda untuk membangun ekonomi bangsa. Journal Transaksi, 4(1), Jakarta: Business Administration Department, Atma Jaya Catholic University of Indonesia.

Cahayani, A., Gunawan, A. S., Iedarwati, P., \& Isololipu, K. (2011). Tinjauan terhadap karakteristik kewirausahaan dalam Diri Wirausahawan Muda (Young Entrepreneur) Alumni FIABIKOM. Paper presentation presented at Atma Jaya Award 2012.

Ciputra. (2009). Ciputra quantum leap. PT. Elex Media Komputindo, Jakarta: Gramedia.

Hisrich, R. D., Peters, M. P., \& Sheperd, D. A. (2013). Entrepreneurship (9th ed.). Boston: McGraw-Hill.

Iedarwati, P., Isololipu, K., \& Cahayani, A. (2010). Jiwa kewirausahaan di kalangan wirausaha perempuan anggota koperasi di Kabupaten Bojonegoro, Jawa Timur. Paper presentation presented at Atma Jaya Award 2011.

Indonesian Ministry of Trade. (2008). Rencana pengembangan 14 subsektor industri kreatif 2009-2015. Retrieved from https://id.scribd.com/doc/38804198/Buku-3-an-Industri-Kreatif-Menuju-Visi-Ekonomi-Kreatif-Indonesia-2025

Iwantono, S. (2002). Kiat sukses berwirausaha: Strategi baru mengelola usaha kecil dan menengah. Jakarta: Gramedia Widiasarana Indonesia.

Kuratko, D. F., \& Hodgetts, R. M. (2007). Entrepreneurship: Theory, process, practice (7th ed.). Ohio: Thomson.

Longenecker, J. G., Moore, C. W., \& Petty, J. W. (2001). Kewirausahaan: Manajemen usaha kecil. (Salemba Empat Team, Trans.). Jakarta: Salemba Empat.

Margiman. (2008). Quo vadis kewirausahaan di Indonesia. Retrieved from http://www.ciputra.org/node/95/quo-vadis-kewirausahaan-di-indonesia.htm

Meredith, G. G. (2002). Kewirausahaan: Teori \& praktek (Suryana, Trans.). Jakarta: PPM.

Nur Maftuhah, G. (2012). Indonesia tak cuma bermimpi miliki 2\% pengusaha. Retrieved from http://economy.okezone.com/read/2012/10/15/320/704303/indonesia-tak-cuma-bermimpi-miliki-2-pengusaha

Soesarsono. (2002). Pengantar kewirausahaan (1st ed.). Bogor: Bogor Agricultural Institute.

Sundari. (2012). Pemerintah minta anak muda bangun ekonomi kreatif. Retrieved from http://www.tempo.co/read/news/2012/09/19/092430417/Pemerintah-Minta-Anak-Muda-Bangun-Ekonomi-Kreatif

Sutanto, A. (2002). Kewiraswastaan. Malang: Ghalia.

Wickham, P. A. (2004). Strategic entrepreneurship (3rd ed.). Essex: Prentice Hall. 